\title{
Learning the parabola through semiotic records in university students
}

\section{Aprendizaje de la parábola mediante registros semióticos en estudiantes universitarios}

ENCINAS-PABLOS, Francisco Javier $\dagger$, PERALTA-GARCÍA, Julia Xochilt, CUEVAS-SALAZAR, Omar and OSORIO-SÁNCHEZ, Mucio

Instituto Tecnológico de Sonora. Cd. Obregón Sonora México, 5 de febrero 818 Sur, CP 85000, Mexico

ID $1^{\text {st }}$ Author: Francisco Javier, Encinas-Pablos / ORC ID: 0000-0003-3859-680X, Researcher ID Thomson: S-69442018, CVU CONACYT ID: 947291

ID $1^{\text {st }}$ Co-author: Julia Xochilt, Peralta-García / ORC ID: 0000-0002-2598-5825, arXiv ID Author: 2764706, CVU CONACYT ID: 89800

ID $2^{\text {nd }}$ Co-author: Omar, Cuevas-Salazar / ORC ID: 0000-0003-0113-0475, Researcher ID Thomson: O-9522-2014, CVU CONACYT ID: 257896

ID $3^{\text {rd }}$ Co-author: Mucio, Osorio-Sánchez / ORC ID: 0000-0002-5448-8393, Researcher ID Thomson: ABB-7912-2020, CVU CONACYT ID: 80565

DOI: $10.35429 / J M Q M .2020 .7 .4 .16 .25$

Received July 20, 2020; Accepted December 30, 2020

\section{Abstract}

Learning achieved by students in their first course of mathematics at the university reflects a low achievement, which is especially observed in the topic of the parabola. Due to this problem, the objective of improving the academic achievement of students in that topic, through a didactic strategy based on semiotic representations, was proposed. To this end, a quantitative inquiry was carried out, with a pre-test post-test design, on both a control group and an experimental group. There, a total of 44 students, of an average age of 19 years who were taking the subject of Mathematics Foundations, participated. It was found that the gain between the post-test and pre-test measurement was significantly higher $(p<0.01)$ in the experimental group with respect to the control group, where the conventional strategy for the course was being used. It is concluded that it is possible to improve the learning of the parabola in students through the strategy based on semiotic representations, and that it is highly recommended to apply it for the learning of other mathematical objects in the basic sciences courses of the engineering division.

\section{Resumen}

Los aprendizajes que logran los estudiantes en el primer curso de matemáticas de la universidad reflejan un bajo aprovechamiento y esto se observa sobre todo en el tema de la parábola. Por ello se planteó el objetivo de mejorar el aprovechamiento académico de los estudiantes en este tema a través de una estrategia didáctica basada en las representaciones semióticas. Con este fin se llevó a cabo una indagación de tipo cuantitativa, con un diseño pretest-postest, con un grupo control y otro experimental, donde participaron un total de 44 estudiantes con una edad promedio de 19 años que cursaban la asignatura de Fundamentos de Matemáticas. Se encontró que la ganancia entre la medida postest y pretest fue significativamente mayor $(\mathrm{p}<0.01)$ en el grupo experimental con respecto al grupo control donde se empleó la estrategia convencional del curso. Se concluye que es posible mejorar el aprendizaje de la parábola en los estudiantes a través de esta estrategia basada en representaciones semióticas y que es altamente recomendable utilizarla en el aprendizaje de otros objetos matemáticos en los cursos de ciencias básicas de la división de ingeniería.

Aprendizaje, Parábola, Representación Semiótica and Quantitative Methods. 2020. 4-7:16-25.

$\dagger$ Researcher contributing as first author. 


\section{Introduction}

Most of the students have problems understanding and using mathematical knowledge, which is reflected in a low index of academic performance, this is shown by the Unesco Institute of Statistics (UIS)... "More than 617 million children and adolescents do not they are reaching the minimum levels of proficiency in reading and mathematics" (UIS, 2017).

Among the standardized tests to measure the basic learning of students is the PISA test (Program for International Student Assessment), developed by the OECD (Organization for Economic Cooperation and Development), which shows the skills acquired by the student in the third year high school in science, reading and math. In 2015, the mathematics competencies shown by Mexican students reached a score of 408, below the OECD average of 493 points. For 2018 the performance was 409 and the OECD average 489. Furthermore, in 2015 less than $1 \%$ of Mexican students achieved higher levels of proficiency (levels 5 and 6), for $20181 \%$ reached those levels. So the last PISA test of 2018 compared on average with the previous ones from 2006 do not show significant differences (OECD, 2019).

In Mexico there are some tests such as the EXHCOBA exam (Examination of Basic Skills and Knowledge), which is applied to students who graduate from high school and aspire to enter university. The results obtained in mathematics confirm that students do not understand basic concepts, do not have problem-solving skills, and the knowledge acquired is related to memorization (Larrazolo, Backhoff \& Tirado, 2013).

Another of the standardized tests applied at the high school level is the PLANEA test, in the last evaluation in 2017 it is reported that the score achieved by high school students was 500 points which corresponds to Level I. The students were able to solve problems related to whole numbers and decimals but did not show algebraic skills at that level of development (National Institute for the Evaluation of Education (INEE), 2019).
It is expected that students at the high school level achieve a mastery of the algebraic rules, understand some mathematical functions establishing its formula and from it its graph and vice versa, as well as construct and interpret mathematical models using arithmetic, algebraic, geometric and variation records, to understand and analyze various situations (INEE, 2019). But according to the results shown by these tests, students fail to achieve these domains in mathematics.

This is observed in the first mathematics courses of higher education, the previous knowledge acquired by the students is very deficient, which hinders the learning of new knowledge to achieve a meaningful learning of mathematics. In the case of this research, an important topic in mathematics that was addressed is that of second degree equations.

At the Technological Institute of Sonora (ITSON), several studies have been prepared to find out the status of the learning problems of their students, for example Sotelo, Echeverría and Ramos (2009) mention that "over $65 \%$ of students drop out of one or more subjects in a school year". Following this same line of research, in another report issued by ITSON, of all the careers from the 2002 to 2006 generation it was found that $53 \%$ of the students dropped out of one or more subjects.

In a study with students new to ITSON engineering careers, it is mentioned that since 2009 a preparatory course has been offered to students who do not pass a diagnostic math exam, seeking to improve their skills in topics related to Algebra, Trigonometry and Analytical Geometry (Peralta, Encinas, Rojas, Cuevas, Ansaldo and Osorio, 2013).

The Academy of the Fundamentals of Mathematics course has reported that the failure rate has increased from $31 \%$ in 2010 to $44.8 \%$ in 2017. While the group average, in the same period, has gone from 5.3 to 5.7. Results that have had a negative impact on the indicators of Educational Programs such as lag and terminal efficiency, so it is important to make improvements in the teaching and learning process in mathematics courses by designing and implementing new strategies didactics and in this way have a positive impact on this problem. 
The contributions to the field of educational mathematics by researchers and teachers with experience in mathematics learning problems, point out the importance of the use of various representation systems, as well as the use of didactic and technological tools to structure and direct the teaching and learning of mathematics in general, and in particular of quadratic equations, Campos (2003), Hitt (2008), Pizarro (2009), Bernal (2020), Campos and Rodríguez (2020), Farabello and Trigueros (2020) ), among others.

It is important to reconsider the role that teachers have in the teaching of mathematics, not to be only transmitters of knowledge, but to consider making an analysis of the difficulties that students show when they want to acquire mathematical knowledge, such is the case of the study of the parable. Therefore, it will be necessary from the difficulties shown by the student to promote different teaching strategies, involving the use of technology in the classroom and encouraging the student to want to learn (Sánchez, 2016).

Various investigations in relation to the parable show how the teacher can consider other ways of approaching its study in the classroom. In an investigation carried out for secondary school teachers, a workshop was developed and the difficulty of solving problems related to the parabola was detected in them, because it was identified that the learning of this object focuses more attention on the algebraic treatment than on the geometric aspect. Therefore, the proposal by Torres, Advíncula, León and Flores (2019) promotes the use of concrete materials and the use of Geogebra, to develop the knowledge of the parabola as a geometric place and thus study its properties. In another research carried out by Aldama and López (2018) they show that in order to achieve a better understanding of this mathematical object, it is necessary to investigate the historical part and origin of the concept, as well as its didactics and develop sequences supported with Geogebra. On the other hand, Cruz, Báez and Corona-Galindo (2018), in a study related to the teaching and learning of the parable, propose a didactic strategy based on meaningful and constructivist learning, called the Potentially Significant Teaching Unit. Therefore, he focuses his attention on this as a geometric place, until the concepts learned from the parable get the students to solve a real problem.
It is important to consider the role of the teacher in the educational process, according to Díaz-Barriga and Hernández (2010), every teacher must acquire and deepen a theoretical framework that helps them understand the teaching process to achieve meaningful learning in the student. Being able to reflect on their own work and promote innovative didactic strategies.

\section{Objectives}

\section{General purpose}

Improve the academic achievement of students in the topic of the parable through a didactic strategy based on semiotic representations with the purpose of improving indicators of the ITSON Engineering Educational Programs.

\section{Specific objectives}

- Design a questionnaire based on the framework of Duval's semiotic representations, using a table of specifications, to measure academic achievement on the subject of the parable.

- Implement an unconventional didactic strategy in the learning of the parable, based on Duval's semiotic representations in an experimental group.

- Apply the designed instrument to the experimental group and to a control group exposed to a conventional strategy, at two different times, before and after the teaching-learning process.

\section{Justification}

Researchers and teachers have been concerned to understand the problems that students have in learning mathematics. The process of teaching and learning requires reformulating the work of the teacher and the student, involving new tools for their work in the classroom. The implementation of new didactic proposals is intended to improve the understanding of mathematics (Sánchez, 2016). 
On the other hand, according to Pizarro (2009); Campos (2003) and Hitt (2008) the contributions in the field of educational mathematics, point out the importance of the use of various semiotic representation systems, as well as the use of didactic and technological tools to restructure and direct teaching and learning of mathematics, in particular that of quadratic equations.

The proposal designed in this research for the teaching and learning of the parable, intends to improve the understanding of this topic. Thus, helping to increase the approval rate, decrease the dropout and lag rates of students. For what it will positively impact and to a certain extent, with the terminal efficiency of the various engineering careers, these indicators are important for accrediting bodies such as the CACEI Council for the Accreditation of Engineering Teaching (CACEI, 2018).

\section{Theoretical framework}

For a learning to be remembered at the required moment it is necessary that it has been apprehended in a meaningful way, that is, that when the learner comes into contact with the new content to be learned, they do so by connecting their previous knowledge with that content. new knowing. It is through this process that the cognitive structure of the learning subject deepens and branches, generating new structures and connections each time it interacts with more and more learning content. In such a way that if a part of this structure is activated, the subject manages to remember other contents thanks to those connections (Díaz-Barriga \& Hernández, 2010).

For subjects to learn meaningfully, two things need to happen. The first is that learners are willing to relate the new content to their previous knowledge in order to give them meaning. The second has to do with the content to be learned, it must have a certain organization or structure that is potentially related to the prior knowledge of the learners. Hence the idea of finding out in advance what the apprentices already know and teaching accordingly (Moreira, 2012).
Therefore, it is important to know what prior knowledge students have when they are going to be taught new content. Find out what they already know and what they don't know. With this knowledge, it is possible to establish a starting point in the teaching of new content, in order to promote that students can develop their learning in a meaningful way.

An important element to consider in the foundation of a didactic proposal on mathematical objects is Raymond Duval's theory of semiotic representation registers, which are currently considered of utmost importance in learning mathematics (Duval, 1998, 2010).

\section{Theory of records of semiotic representation}

The use of semiotic representations of the quadratic function offers a variety of very particular features in each of them, which facilitate the development of cognitive activities, when in the teaching and learning process conversion activities between representations are promoted: algebraic, graphical, tabular and verbal.

Duval (1998) mentions that "a writing, a notation, the strokes, the figures represent mathematical objects such as: a number, a function, a vector, a segment, a point, a circle" and affirms that mathematical objects they should not be confused with their representations.

The use of semiotic representations of Raymond Duval are considered of utmost importance in learning mathematics (Duval, 1998, 2010). The Parabola can be represented by various graphic, algebraic, verbal or tabular registers. Which are necessary in mathematical activity, in order to interact with the object (Duval, 1998).

Duval structures in the theory of semiotic representations three cognitive activities related to semiotic representation registers: Formation, Treatment and Conversion. Substantial and necessary for the understanding and communication of mathematics (Godino, Wihelmi, Blanco, Contreras and Giacomone, 2016; Duval, 1988). 
Training is an activity associated with the apprehension of semiotic representations and has to do with the signs that characterize each record and their identification rules in the same record. In the Treatment activity, the transformation of the representation of the mathematical object occurs but within the same record. Finally, Conversion, which is the transformation of a representation into another register, whose activity is considered very essential because it plays a fundamental role in the conceptualization of represented content (Duval, 1998, 2012).

The Training activity is exemplified when there is a representation of the form $y=$ $a x^{\wedge} 2+b x+c$, in the algebraic register. And if this representation is transformed to the form $y$ $=(\mathrm{x}+\mathrm{h}) \wedge 2+\mathrm{k}$ then it is the Treatment activity. And the Conversion activity when this quadratic equation is represented in the graphical register with a trace, identifying each element of the equation with the corresponding element in the graph.

\section{Research methodology}

The type of research that was carried out, which subjects participated in the study, what instrument was used to gather information and the procedure or steps carried out in the investigation is detailed below.

Kind of investigation

The inquiry was quantitative, quasiexperimental with a pretest-posttest design with a control group (Buendía, Colás and Hernández, 1998).

\section{Subjects}

The study included 44 students who were taking the subject Fundamentals of Mathematics, with an average age of 19 years. Two groups of already conformed students were randomly selected, one experimental and one control. The first was made up of 24 students, 12 of whom were women and 12 men; the second group consisted of 20 students, of whom eight were women and 12 men.

\section{Instrument}

The questionnaire used in the inquiry consisted of nine items. Three of them were used for students to reflect the cognitive activity of Treatment: verbal, algebraic and graphic respectively. The other six items were designed for students to show the cognitive activity of Conversion of the following records: from verbal to algebraic, from verbal to graphic, from algebraic to verbal, from algebraic to graphic, from graphic to verbal and from graphic to algebraic.

The tasks requested by the reagents were the following:

\begin{tabular}{|c|c|c|}
\hline $\mathbf{R}$ & $\begin{array}{l}\text { Registry } \\
\text { Start- } \\
\text { End }\end{array}$ & Task \\
\hline 1 & $\mathrm{~V}-\mathrm{V}$ & $\begin{array}{l}\text { The verbal equivalent of a quadratic } \\
\text { equation with a parabola. }\end{array}$ \\
\hline 2 & A-A & $\begin{array}{l}\text { It asks to pass the expression } \\
y=(x-b) 2+c \text { to } y=a x 2+p x+q .\end{array}$ \\
\hline 3 & G-G & $\begin{array}{l}\text { Identify over what interval a function } \\
\text { grows. }\end{array}$ \\
\hline 4 & V-A & From a sentence identify its equation. \\
\hline 5 & $\mathrm{~A}-\mathrm{V}$ & $\begin{array}{l}\text { Convert the } \\
\begin{array}{l}(a-b)(a+b)=a 2-\quad b 2 \\
\text { statement. }\end{array}\end{array}$ \\
\hline 6 & V-G & From a sentence identify its graph. \\
\hline 7 & G-V & $\begin{array}{l}\text { A graph is shown and its statement is } \\
\text { requested. }\end{array}$ \\
\hline 8 & A-G & $\begin{array}{l}\text { An equation is offered and asked to } \\
\text { identify its graph. }\end{array}$ \\
\hline 9 & G-A & Given a graph identify its equation. \\
\hline
\end{tabular}

Table 1 Task requested by each instrument reagent

Process

The first step was to develop the measurement instrument, based on Duval's (1998) conceptual framework of semiotic representations. The records were considered: verbal, algebraic and graphic of the parabola as they are the most used in the mathematical literature. A table of specifications was used in order to achieve the content validity of the instrument, according to the recommendations of Santibañez (2011). Subsequently, the instrument was presented to three experts in the area to validate its content. A pilot test was then carried out with a group of students to review the writing of the items, until it was in its final version. 
Subsequently, and in accordance with the recommendations of Díaz and Leyva (2013), the difficulty indices of the items were classified as follows: more than 0.9 would be considered the easy item, between 0.8 and 0.89 the item would be moderately easy, between 0.7 and 0.79 would be of medium difficulty, between 0.5 and 0.69 would be moderately difficult and less than 0.5 would be considered difficult items. According to the research design, the instrument was applied to both the control and the experimental group before starting the learning of the parable topic (pretest) and after the teaching process (posttest). In the control group a conventional sequence of the course was applied while in the experimental group the new didactic sequence was implemented.

With the data collected through the instrument, it was possible to identify those Treatments and Conversions with which the students show difficulties and strengths through descriptive statistics. The Shapiro Wilk test was performed to verify that the data met the normality assumption. It was found that the pretest and posttest data of the control group fulfilled this assumption, but not the data of the experimental group. Therefore, the Wilcoxon paired comparison test was used to determine the existence of a significant difference between the groups, both in the pretest and in the posttest, as well as in their gain, as recommended by Hernández, Fernández and Baptista (2014). With the results obtained, it was possible to achieve the objective of the investigation to finally write the corresponding report.

\section{Results}

When applying the measurement instrument at the pretest moment, it was found that the groups were not equal in terms of prior knowledge of the parabola (Table 2). There was a significant difference between the control and experimental groups $(\mathrm{p}<0.05)$. The control group obtained an average score higher than the experimental group from 0.18 to 2.1 points. This situation may be due to the fact that the university receives high school students with very diverse training programs, which is reflected in a different level of prior knowledge. Thus, from the outset, the control group showed a higher starting point than the experimental group in terms of prior knowledge of the parable.

\begin{tabular}{|l|r|r|r|}
\hline Group & \multicolumn{1}{|c|}{ Pretest } & Postest & Gain \\
\hline Control & 6.10 & 6.60 & 0.50 \\
\hline Experimental & 4.96 & 6.88 & 1.92 \\
\hline
\end{tabular}

Table 2 Average number of correct items in each group out of a total of nine items

After the pretest and after having exposed the control and experimental group to two different didactic sequences, the instrument was applied again at a posttest moment. Here both groups showed similar academic achievement since it was not found that there was a significant difference between them at that time ( $p>0.05)$. However, when comparing each group with itself between the pretest and posttest, it was found that in the control group there were no significant advances, since there was no increase in their score $(p>0.05)$. Not so in the experimental group that did show a highly significant advance in their grade ( $p$ $<0.01$ ), which increased on average from 1.26 to 2.57 points. When making a comparison of the gain between both groups, a highly significant difference was also found between them $(\mathrm{p}<0.01)$. The experimental group had a gain greater than that of the control from 0.53 to 2.31 points. This result is consistent with other studies that have also implemented learning tasks aimed at students working on different semiotic representations, such as the works reported by Prada, Hernández and Jaimes (2017), Mercedes, Pérez and Triana (2017), Aznar, Distéfano, Moler and Pesa (2018), Denardi and Bisognin (2020), among others. The results obtained by the groups in their notes, therefore, show that the didactic sequence based on semiotic representations offers better learning results than the conventional didactic sequence of the course.

On the other hand, the result observed in the experimental group with respect to the gain in the average of their grade, was also recorded in the gain obtained by the group in the two cognitive activities evaluated (Table 3). Although the pre-test starting point showed that the control group started with a better position in the Treatment and Conversion activities than the experimental group, at the post-test moment this difference was canceled. This caused that again, with regard to the gain in the two cognitive activities that were evaluated, a significant difference was observed in favor of the experimental group over the control, with respect to Treatment ( $\mathrm{p}<0.01)$, and Conversion $(\mathrm{p}<0.05)$.

ENCINAS-PABLOS, Francisco Javier, PERALTA-GARCÍA, Julia Xochilt, CUEVAS-SALAZAR, Omar and OSORIO-SÁNCHEZ, Mucio. Learning the parabola through semiotic records in university students. Journal-Mathematical and Quantitative Methods. 2020 
As the ability to perform record conversions is evidence of the deep understanding of the mathematical object Duval (1988), then the didactic sequence based on semiotic registers offers in terms of apprehension greater gain and a steeper learning curve than the conventional didactic sequence. of the course of foundations on the theme of the parable. Due to all of the above, these results bring with them some practical implications both for the fundamentals course and for other subjects in the area, since a didactic sequence similar to that of this research could be implemented in other mathematical objects, with good expectations of success.

\begin{tabular}{|l|c|c|c|c|c|c|}
\hline \multicolumn{1}{c}{\begin{tabular}{c} 
Cognitive \\
\multicolumn{1}{c}{ activity }
\end{tabular}} & GC & GE & \multicolumn{1}{c}{ Postest } & \multicolumn{2}{c|}{ Gain } \\
\hline Treatment & 0.62 & 0.49 & 0.63 & 0.65 & 0.01 & 0.16 \\
\hline Conversion & 0.71 & 0.58 & 0.78 & 0.82 & 0.07 & 0.24 \\
\hline Note. CG $=$ control group; EG = experimental group. \\
\hline
\end{tabular}

Table 3 Average difficulty index for cognitive activity

In relation to each of the reagents of the instrument that was used to evaluate the ability of the subjects to perform Treatments and Conversions in the graphic, algebraic and verbal records (Table 4). The results indicate that at the beginning, at the pretest moment, the control group had a better starting point than the experimental group in terms of these cognitive abilities. Condition that changed at the post-test moment, where the groups performed equivalently in most of the tasks. However, again the gain observed in the experimental group was higher compared to the control group in the three Treatment tasks and in five of the six Conversion tasks. In the control group (Table 5) the difficulty index did not change in the Treatment tasks (AA, GG, VV) and in three Conversion tasks (GA, VG, GV) between the pretest - posttest measurements, while in the The experimental group did show improvements in the difficulty index in two Treatments (VV, GG) and in five Conversions (AG, GA, GV, AV, VG). This offers evidence that the didactic sequence applied in the experimental group offers better learning results than the conventional sequence applied in the control group.

\begin{tabular}{|c|c|c|c|c|c|c|c|}
\hline \multirow[t]{2}{*}{$\mathbf{A C}$} & \multirow{2}{*}{$\begin{array}{l}\text { Registry } \\
\text { Start-End }\end{array}$} & \multicolumn{2}{|c|}{ Pretest } & \multicolumn{2}{|c|}{ Postest } & \multicolumn{2}{|c|}{ Gain } \\
\hline & & GC & GE & GC & GE & GC & GE \\
\hline $\mathrm{T}$ & G-G & 0.50 & 0.29 & 0.55 & 0.58 & 0.05 & 0.29 \\
\hline $\mathrm{T}$ & A-A & 0.40 & 0.29 & 0.35 & 0.42 & -0.05 & 0.13 \\
\hline $\mathrm{T}$ & $\mathrm{V}-\mathrm{V}$ & 0.95 & 0.88 & 1.00 & 0.96 & 0.05 & 0.08 \\
\hline C & G-A & 0.60 & 0.00 & 0.65 & 0.79 & 0.05 & 0.79 \\
\hline $\mathrm{C}$ & $A-V$ & 0.45 & 0.24 & 0.70 & 0.58 & 0.25 & 0.34 \\
\hline C & A-G & 0.95 & 0.79 & 0.85 & 1.00 & -0.10 & 0.21 \\
\hline $\mathrm{C}$ & V-G & 0.60 & 0.46 & 0.60 & 0.67 & 0.00 & 0.21 \\
\hline $\mathrm{C}$ & G-V & 0.95 & 0.83 & 1.00 & 1.00 & 0.05 & 0.17 \\
\hline $\mathrm{C}$ & V-A & 0.70 & 0.88 & 0.90 & 0.88 & 0.20 & 0.00 \\
\hline & & & & & & & $\begin{array}{l}A= \\
\text { itive }\end{array}$ \\
\hline
\end{tabular}

Table 4 Difficulty index of the reagents in the control (CG) and experimental (EG) group, at the pretest and posttest time, and the gain between these two measurements

\begin{tabular}{|l|l|l|l|l|l|}
\hline AC & \multicolumn{1}{c}{$\begin{array}{c}\text { Registry } \\
\text { Start-End }\end{array}$} & \multicolumn{1}{c}{ GC } & \multicolumn{1}{c|}{ GE } & \multicolumn{1}{c|}{ GC } & \multicolumn{1}{c|}{ GE } \\
\hline T & G-G & MD & D & MD & MD \\
\hline T & A-A & D & D & D & D \\
\hline T & V-V & F & MF & F & F \\
\hline C & G-A & MD & D & MD & DM \\
\hline C & A-V & D & D & DM & MD \\
\hline C & A-G & F & DM & MF & F \\
\hline C & V-G & MD & D & MD & MD \\
\hline C & G-V & F & MF & F & F \\
\hline C & V-A & DM & MF & F & MF \\
\hline $\begin{array}{l}\text { Note. F = easy; MF = moderately easy; DM = medium } \\
\text { difficulty; MD = moderately difficult; D = difficult }\end{array}$ \\
\hline
\end{tabular}

Table 5 Difficulty index (according to their classification) of each item in the control (CG) and experimental (EG) group, at the pre-test and post-test time

On the other hand, it was observed that the Algebraic Treatment (AA) is the most difficult in both study groups even after the teaching process, since it did not change its difficulty index between the pretest and posttest (Table 5), these problems with algebra coincide with studies carried out by García, Segovia and Lupiáñez (2011), Rodríguez and Torrealba (2016). What makes it clear that algebra is a content little understood by students, who have deficiencies in this area since high school, as shown by the results of the Planea exam (Ministry of Public Education, n.d.).

In addition, three tasks with moderate difficulty were also found in the experimental group at the post-test moment. The A-V and V$\mathrm{G}$ Conversions and the $\mathrm{G}-\mathrm{G}$ Treatment. The latter usually represents a problem for students, who struggle with the reading and interpretation of graphic records, as also reported by Guerrero, Camacho and Mejía (2010), Artola, Mayoral and Benarroch (2016). 
Therefore, the A-A and G-G Treatments, as well as the A-V and $\mathrm{V}-\mathrm{G}$ Conversions for the next school year are identified as areas of opportunity in the teaching of the parable.

\section{Conclusions}

From the results obtained, it is concluded that it was possible to improve the academic achievement of the students in the theme of the parable through a didactic strategy based on semiotic representations. It was achieved that the students had a steeper learning curve, and in turn, some areas of opportunity were identified for the teaching of this mathematical object in which special attention must be paid in the future, such as: Treatments in the algebraic register (AA) and in the graphic register (GG), as well as in the Conversions from the algebraic register to the verbal (AV) and from the verbal register to the graph (VG).

It is recommended to use this didactic strategy in other subjects of the mathematics fundamentals course where there are similar learning problems and also to use it in the teaching and learning of mathematical objects in other subjects in the basic sciences area of the curricula plans of engineering educational programs.

\section{References}

Aldana, E., \& López, J. (2018). Estudio histórico-epistemológico y didáctico de la parábola. Praxis \& Saber, 9(19), 63-88. https://doi.org/10.19053/22160159.v9.n19.201 8.7922

Artola, E., Mayoral, L., \& Benarroch, A. (2016). Dificultades de aprendizaje de las representaciones gráficas cartesianas asociadas a biología de poblaciones en estudiantes de educación secundaria. Un estudio semiótico. Revista Eureka Sobre Enseñanza y Divulgación de Las Ciencias, 13(1), 36-52. Recuperado de https://revistas.uca.es/index.php/eureka/article/v iew/2951

Aznar, M., Distéfano, M., Moler, E., \& Pesa, M. (2018). A didactic sequence to improve the conversion of semiotic representations of curves and regions of the complex plane. Uniciencia, 32(1), 46-67. https://doi.org/10.15359/ru.32-1.4
Bernal, C. (2020). Propuesta para la innovación del curso de precálculo: funciones, sus gráficas, dominios y codominios. Recuperado de http://funes.uniandes.edu.co/17269/1/Bernal_C arlos_Eduardo_(2020)_Funciones\%2C_sus_gr $\% \mathrm{C} 3 \%$ A1ficas\%2C_dominios_y_codominios.p df

Buendía, L., Colás, P., \& Hernández, F. (1998). Métodos de investigación en Psicopedagogía. España: McGraw Hill.

Campos, C. (2003). La argumentación gráfica en la transformación de funciones cuadráticas. Una aproximación socioepistemológica. Tesis de Maestría no publicada. Centro de Investigación y Estudios Avanzados del Instituto Politécnico Nacional. México, D.F.

Campos, M., \& Rodríguez, M. (2020). Un estudio sobre la aprehensión conceptual de las inecuaciones. Revista Paradigma, 41, 540-570. Recuperado http://funes.uniandes.edu.co/22158/1/Campos2 020Un.pdf

Consejo de Acreditación de la Enseñanza de la Ingeniería (CACEI). (2018). Marco de referencia 2018. Recuperado de http://cacei.org.mx/nvfs/nvfs02/nvfs0210.php

Cruz, F., Báez, J., \& Corona-Galindo, M. (2018). Estrategia de enseñanza y aprendizaje para el estudio de los elementos característicos de la parábola. El Cálculo y su Enseñanza, Enseñanza de las Ciencias y la Matemática. 11(2). 62-82. Recuperado de https://recacym.org/index.php/recacym/article/v iew/28

Denardi, V., \& Bisognin, E. (2020). Resolução de Problemas e Representações Semióticas na Formação Inicial de Professores de Matemática. Revista De Educação Matemática, 17, e020022.

https://doi.org/10.37001/remat25269062v17id2 72

Díaz-Barriga, F., \& Hernández, G. (2010). Estrategias docentes para un aprendizaje significativo. Una interpretación constructivista. México: Editorial McGrawHill. 
Díaz, P., \& Leyva, E. (2013). Metodología para determinar la calidad de los instrumentos de evaluación. Revista Educación Médica Superior, 27(2), 269-286. Recuperado de http://www.medigraphic.com/pdfs/educacion/ce m-2013/cem132n.pdf

Duval, R. (1988). Graphiques et Equations: l'articulation de deux registres, in Annales de Didactique et de Sciences Cognitives, ${ }^{\circ} 1,235-$ 253. (Versión en español de Blanca M. Parra).

Duval, R. (1998). Registros de representación semiótica y funcionamiento cognitivo del pensamiento. En F. Hitt (Ed.), Investigaciones en Matemática Educativa II (pp. 173-201). México: Grupo Editorial Iberoamérica.

Duval, R. (2010). Sémiosis, pensée humaine et activité mathématique. Revista de Educação em Ciências e Matemáticas, 6(1), 126-143. Recuperado de https://dialnet.unirioja.es/servlet/articulo?codig $\mathrm{o}=5870410$

Duval, R. (2012). Lo esencial de los procesos cognitivos de comprensión en matemáticas: los registros de representación semiótica. En U. Malaspina (Ed.). Resúmenes del VI Coloquio Internacional de Didáctica de las Matemáticas: avances y desafios actuales (pp.14-17). Lima, Peru: Pontificia Universidad Católica del Perú.

Farabello, S., \& Trigueros, M. (2020). La Transformación de Funciones en el aula de Física. UNIÓN Revista Iberoamericana de Educación Matemática, 16(58), 25-47. Recuperado de https://union.fespm.es/index.php/UNION/articl e/view/82/23

García, J., Segovia, I., \& Lupiáñez, J. (2011). Errores y dificultades de estudiantes mexicanos de primer curso universitario en la resolución de tareas algebraicas. En J. L. Lupiáñez, M. C. Cañadas, M. Molina, M. Palarea, y A. Maz (Eds.), Investigaciones en Pensamiento Numérico y Algebraico e Historia de la Matemática y Educación Matemática (pp. 145155). Granada: Dpto. Didáctica de la Matemática, Universidad de Granada. Recuperado de http://funes.uniandes.edu.co/2018/1/GarciaSego viaLupianez2011.pdf
Godino, J., Wihelmi, M., Blanco, T., Contreras, A., \& Giacomone, B. (2016). Análisis de la actividad matemática mediante dos herramientas teóricas: Registros de representación semiótica y configuración ontosemiótica. Avances de Investigación en Educación Matemática, 10, 91-110. Recuperado de https://www.researchgate.net/publication/31010 0320_Analisis_de_la_actividad_matematica_m ediante_dos_herramientas_teoricas_Registros_ de_representacion_semiotica_y_configuracion_ ontosemiotica

Guerrero, C., Camacho, M., \& Mejía, H. (2010). Dificultades de los estudiantes en la interpretación de las soluciones de ecuaciones diferenciales ordinarias que modelan un problema. Enseñanza de las ciencias, 28(3), 341-352. Recuperado de https://www.raco.cat/index.php/Ensenanza/artic le/view/210804/353412

Hernández, R., Fernández, C., \& Baptista, P. (2014). Metodología de la investigación. México: McGraw Hill. Sexta edición.

Hitt, F. (2008). Investigaciones en Ambientes Tecnológicos, Marcos Teóricos y Metodológicos: Un Punto de Vista Pragmático. En Pantoja, R. Añorve, E., Cortés, J., y Osornio, L. (Comp.). Investigaciones y Propuestas sobre el uso de Tecnología en Educación Matemática. (pp. 1-20). México: ITCG.

Instituto Nacional para la Evaluación de la Educación (INEE). (2019). Informe de resultados Planea EMS 2017. Recuperado de https://www.inee.edu.mx/wpcontent/uploads/2019/05/P1D320.pdf

Larrazolo, N., Backhoff, E., \& Tirado, F. (2013). Habilidades de razonamiento matemático de estudiantes de educación media superior en México. Revista Mexicana de Investigación Educativa, 18(59), 1137-1163. Recuperado de https://www.comie.org.mx/revista/v2018/rmie/i ndex.php/nrmie/article/view/283/283 
Mercedes, A., Pérez, O., \& Triana, B. (2017). Propuesta didáctica basada en múltiples formas de representación semiótica de los objetos matemáticos para desarrollar el proceso de enseñanza aprendizaje del cálculo diferencial. Revista Academia y Virtualidad, 10(2), 20-30. https://doi.org/10.18359/ravi.2743

Moreira, M. (2012). ¿Al final, qué es aprendizaje significativo? Revista Qurriculum, 25, 29-56. Recuperado de: http://publica.webs.ull.es/upload/REV\%20QUR RICULUM/25\%20-\%202012/02.pdf

Organización para la Cooperación y el Desarrollo Económico (OCDE). (2019). Programa para la evaluación internacional de alumnos PISA 2018 resultados. Recuperado de https://www.oecd.org/pisa/publications/PISA20 18_CN_MEX_Spanish.pdf

Peralta, J., Encinas, F., Rojas, J., Cuevas, O., Ansaldo, J., \& Osorio, M. (2013). Implementación de la estrategia resolución de problemas en el aprendizaje del tema ecuaciones lineales en alumnos de ingeniería. En Pizá, R., González, M. y Vizcarra, L. (Comp.). Valoración de Indicadores del Desempeño Académico. (pp. 124-135). México: ITSON. Recuperado de https://www.itson.mx/publicaciones/Documents /rada/valoraciondeindicadores.pdf

Pizarro, R. (2009). Las TICs en la enseñanza de las Matemáticas. Buenos Aires Argentina: Universidad Nacional de la Plata.

Prada, R., Hernández, C., \& Jaimes, L. (2017). Representación semiótica de la noción de función: concepciones de los estudiantes que transitan del Colegio a la Universidad. Panorama, 11(20), 34-44. Recuperado de https://journal.poligran.edu.co/index.php/panor ama/article/view/1008/749

Rodríguez, I., \& Torrealba, A. (2016). Dificultades que conducen a errores en el aprendizaje del lenguaje algebraico en estudiantes de tercer año de educación media general. Revista Arjé, 11(20), 416-438. Recuperado de http://arje.bc.uc.edu.ve/arj20/art38.pdf
Sánchez, E. (2016). Algunas dificultades de aprendizaje presentes en el estudio de la parábola como sección cónica. Repositorio Digital IDEP/ B. Currículo y prácticas de enseñanza (pp. 213-230). Bogotá, Colombia. Recuperado de https://repositorio.idep.edu.co/handle/001/2342

Santibañez, J. (2011). Manual para la evaluación del aprendizaje estudiantil. (Primera edición). México: Editorial Trillas.

Secretaría de Educación Pública. (s.f.). Planea, resultados nacionales 2017. Recuperado de http://planea.sep.gob.mx/content/general/docs/2 017/ResultadosNacionalesPlaneaMS2017.PDF

Sotelo, C., Echeverría, C., \& Ramos, E. (2009). Relaciones entre variables motivacionales $y$ rendimiento académico en estudiantes universitarios. Memoria Electrónica del X Congreso Nacional de Investigación Educativa. Veracruz, México.

Torres, I., Advícula, E., León, J., \& Flores, H. (2019). Estudio de la parábola como lugar geométrico: una forma de ampliar el conocimiento especializado del profesor. XV Conferencia Interamericana de Educación Matemática. Conferencia llevada a cabo en Medellín, Colombia. Recuperado de https://conferencia.ciaemredumate.org/index.php/xvciaem/xv/paper/view File/879/117

UNESCO Institute for Statistics (UIS). (2017). More Than One-Half of Children and Adolescents Are Not Learning Worldwide ". Recuperado de http://uis.unesco.org/sites/default/files/documen ts/fs46-more-than-half-children-not-learningen-2017.pdf. 